\title{
APPENDIX
}

\section{Two Separate Genes Involved in Sulphate Transport in Escherichia coli $\mathrm{K} 12$}

\author{
By F. PARRA, P. BRITTON, C. CASTLE, $\dagger$ M. C. JONES-MORTIMER* AND \\ H. L. KORNBERG \\ Department of Biochemistry, University of Cambridge, Tennis Court Road, \\ Cambridge, CB2 $1 Q W$, U.K.
}

\section{INTRODUCTION}

In the course of the experiments described above it became clear that the two cys mutations used were not identical. The cys $A 471$ mutation was isolated by Tully (1976) as conferring resistance to chromate, the cys $Z 474$ mutation arose spontaneously and simultaneously with a ptsI mutation, (it may be the result of an inversion with ends in these two genes). The mapping of the genes (see above, Table 3) shows that cys $A$ and cys $Z$ lie on opposite sides of ptsI. We therefore investigated the biochemical nature of the mutations.

\section{METHODS}

Exponential phase cells growing in minimal medium supplemented with cystine were harvested, resuspended in the sulphur-free medium of Pasternak (1962) with $10 \mathrm{mM}$-gluconate as carbon source and incubated at $37^{\circ} \mathrm{C}$ for $9 \mathrm{~h}$ to derepress the sulphate transport system. The cells were harvested and resuspended in 5 mM-HEPES buffer, $\mathrm{pH} 6.5$, at a concentration of $0.68 \mathrm{mg}$ dry mass $\mathrm{ml}^{-1}$. Radioactive sulphate ${ }^{35} \mathrm{SO}_{4}^{2-}$ ] was added to a final concentration of $0.2 \mathrm{mM}$ and $20 \mu \mathrm{Ci} \mathrm{ml}^{-1}$, and the cells were incubated at room temperature. Samples were taken at 10,60, 120 and $180 \mathrm{~s}$, filtered through an Oxoid membrane filter and washed four times with 2 ml HEPES buffer. The filters were dissolved in $10 \mathrm{ml}$ of scintillation fluid $[0.4 \% 2,5$-diphenyloxazole, $80 \%(\mathrm{v} / \mathrm{v})$ toluene and $20 \%(\mathrm{v} / \mathrm{v})$ methoxyethanol] and their radioactivity was measured in a Packard 3385 scintillation spectrometer. Background measurements were made under identical conditions and samples of $\left[{ }^{35} \mathrm{SO}_{4}^{2-}\right]$ were assayed to convert the disintegrations measured to moles of sulphate ions. All other techniques were as described in the main paper.

\section{RESULTS}

Sulphate transport was assayed in the cysteine auxotrophs JM1783 (cysA) and JM1766 (cysZ) and in isogenic wild-type strains (Table 5). These strains were also tested for their growth response to thiosulphate at $20 \mathrm{~mm}$, a concentration that supports the growth of mutants of Salmonella typhimurium LT2 defective in sulphate transport (Mizobuchi et al., 1962). The results are shown in Table 5. The strains are deficient in sulphate accumulation, but apparently not in the synthesis of cysteine from $O$-acetylserine and sulphide, since they grow when supplemented with $20 \mathrm{~mm}-\mathrm{S}_{2} \mathrm{O}_{3}^{2-}$.

\section{DISCUSSION}

In Salmonella typhimurium LT2 three closely-linked cistrons $c y s A a, A b$ and $A c$ are required for sulphate transport (Howarth, 1958; Mizobuchi et al., 1962; Ohta et al., 1971), though none of these is the structural gene for the sulphate binding protein. A deletion of all three cistrons (Howarth, 1958) was not reported as being deficient in glucose utilization, suggesting that the known Salmonella cys $A$ cistrons do not bracket pts $H$ and $I$. Karbonowska et al. (1977) indicate that the cys $A$ chromate-resistant mutations of $E$. coli and $S$. typhimurium are probably in corresponding cistrons. If this is so, the $p t s H$ and $p t s I$ genes of Salmonella are inverted relative to cys $A$.

† Present address: Department of Biochemistry, Imperial College of Science and Technology, London SW7 2AZ, U.K. 
Table 5. Properties of the sulphate transport deficient mutants

Sulphate transport was measured after $9 \mathrm{~h}$ of sulphur starvation as described in Methods.

\begin{tabular}{|c|c|c|c|c|}
\hline \multirow[b]{2}{*}{ Strain } & \multirow[b]{2}{*}{$\begin{array}{l}\text { Pertinent } \\
\text { genotype }\end{array}$} & \multicolumn{2}{|c|}{ Growth } & \multirow[b]{2}{*}{ 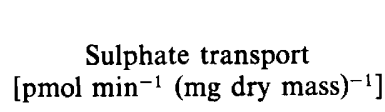 } \\
\hline & & $-\mathrm{S}_{2} \mathrm{O}_{3}^{2-}$ & $+\mathrm{S}_{2} \mathrm{O}_{3}^{2-}$ & \\
\hline JM1783 & cys $^{+}$ & + & + & 260 \\
\hline JM1781 & cys A47I & - & + & 40 \\
\hline CBK 110 & cys $^{+}$ & + & + & 275 \\
\hline JM1766 & cys $Z 474$ & - & + & 65 \\
\hline
\end{tabular}

We have not assayed our cys mutants for any of the enzymes of cysteine biosynthesis, most of the structural genes for which map elsewhere (Jones-Mortimer, 1968, 1973) but the growth of the mutants on medium supplemented with $20 \mathrm{~mm}$-thiosulphate indicates that at least one of the isoenzymes of $O$-acetylserine sulphydrase (Kredich et al., 1980) is present in the strains. In Salmonella the genes for both isoenzymes map near ptsI (Kredich et al., 1980). Wiater \& Hulanicka (1979) demonstrated a deficiency in sulphate transport in cysK mutants of $E$. coli. These, like the cys $K$ mutants of $S$. typhimurium are defective in $O$-acetylserine sulphydrase-A (Hulanicka et al., 1975). Our (unpublished) experiments indicate that the cys $Z$ gene cannot be identical with $\operatorname{cys} K$, since a plasmid carrying the $c y s K^{+}$gene did not complement the cys $Z$ defect.

Since $\mathrm{SO}_{4}^{2-}$ ions that enter the cells can presumably be metabolized in the mutants as well as in the wild-type strains, the observed rates of assimilation must represent the sum of transport and metabolism.

\section{REFERENCES}

Jones-Mortimer, M. C. (1968). Positive control of sulphate reduction in Escherichia coli: isolation, characterisation and mapping of cysteineless mutants of E. coli K12. Biochemical Journal 110, 589595.

JoNES-MORTIMER, M. C. (1973). Mapping of structural genes for the enzymes of cysteine biosynthesis in Escherichia coli $\mathrm{K} 12$ and Salmonella typhimurium LT2. Heredity 31, 213-221.

HowarTH, S. (1958). Suppressor mutations in some cystine-requiring mutants of Salmonella typhimurium. Genetics 43, 404-418.

Hulanicka, M. D., Kredich, N. M. \& Treiman, D. M. (1974). The structural gene for $O$-acetylserine sulfhydrase A in Salmonella typhimurium: identity with the $\operatorname{trz} A$ locus. Journal of Biological Chemistry 249, 867-872.

Karbonowska, H., Wiater, A. \& Hulanicka, M . D. (1977). Sulphate permease of Escherichia coli K12. Acta biochimica polonica 24, 329-334.
Kredich, N. M., Hulanicka, M. D. \& Hallquist, S. G. (1980). Synthesis of L-cysteine in Salmonella typhimurium. Ciba Foundation Symposia 72, 87-99.

Mizobuchi, K., Demerec, M. \& Gillespie, D. H. (1962). Cysteine mutants of Salmonella typhimurium. Genetics 47, 1617-1627.

OHTA, N., Galsworthy, P. R. \& PARdee, A. B. (1971). Genetics of sulphate transport by Salmonella typhimurium. Journal of Bacteriology 105, 1053-1062.

Pasternak, C. A. (1962). Sulphate activation and its control in Escherichia coli and Bacillus subtilis. Biochemical Journal 85, 44-49.

Tully, M. J. (1976). Genetical and biochemical investigations on regulation of cysteine biosynthesis in E. coli. D.Phil. thesis, University of Oxford.

Wiater, A. \& HulaniCKa, M. D. (1979). Properties of cysK mutants of Escherichia coli $\mathbf{K} 12$. Acta biochimica polonica 26, 21-28. 